\title{
A Brief Analysis of Teachers' Major Roles in Learner Autonomy in English Teaching \\ Xiu Zeng
}

Foreign Language School, Nanchang Normal University, Nanchang, Jiangxi, 330032

2267395464@qq.com

Keywords: Teachers' roles; Learner autonomy; English teaching; Analysis

\begin{abstract}
Learner autonomy has recently been introduced to China as one of the efficacious, potential-developing teaching patterns. Increasing attention has been drawn to the importance of autonomy in language learning and teaching. Autonomy has in fact become a central theme in language instruction. Autonomy will facilitate learners to apply the knowledge acquired in a given context to different situations. However, learner's autonomy cannot be analyzed and fulfilled thoroughly without taking account of teachers' roles in correlated interaction of teaching and learning. Based on its nature and its great effect on the promotion of language teaching, this paper chiefly centers around the major roles English teachers play in learner autonomy and their contribution to the development of language teaching.
\end{abstract}

\section{Introduction}

Learner autonomy in foreign language teaching and learning has been a favorite topic for a long time. There have been lots of studies to promote learner autonomy in different levels of language education. Helping learners to become autonomous is one of the fundamental and universal duties of teachers. Teacher role and learner role is an integral part in autonomous learning. Autonomy requires the understanding of new roles between both teachers and learners. It is necessary for them to change their roles so as to adapt themselves to the new requirements of autonomy. The promotion of autonomy is dependent greatly on how teachers are aware of their new roles. Traditionally, teachers dominates the whole process of teaching, they give lectures just like a king giving orders for students to follow while students, just sit waiting to be taught. Students have not many ideas about what to learn and how to learn. There is not much effective communication in class between teachers and students. Such a situation may likely result in either less school attendance or more absence of mind. Therefore, teachers need shift their traditional roles and adapt themselves to perform a variety of new roles required in learner autonomy.

\section{The Theoretical Background}

The concept of learner autonomy has been introduced into foreign language teaching over thirty years. It was first defined in terms of ability or capacity. Henri Holec [1] defines learner autonomy as "the ability to take charge of one's own learning". He also notes that this ability "is not inborn but must be acquired either by 'natural' means or by formal learning". Holec [1] has been a major influence in autonomy and his initial definition has been taken as a starting point in following research of autonomy.

Dickinson [2] accepts the definition of autonomy as a 'situation in which the learner is totally responsible for all of the decision concerned with his learning. Little [3] sees learner autonomy as 'essentially a matter of the learner's psychological relation to the process and content of learning'. Kenny [4] states that autonomy is not only the freedom to learn but also 'the opportunity to become a person'.

The above definitions focus on students' personal growth and life-long development in language learning, yet all these cannot be achieved without teachers' proper motivation and guidance. Teachers hold a position as important as learners do in learner autonomy. It is reasonable to say 
that it is difficult and even impossible for learners to depend totally on themselves, especially in its early stage. The following is the major roles English teachers are expected to play in learner autonomy.

\section{Roles Required for Teachers in Learner Autonomy}

The ever-increasing necessity for teaching students how to become independent and autonomous learners has brought new perspectives to the teaching profession and changed traditional ideas about language teachers' roles. The following will be the roles teachers are supposed to play in learner autonomy.

Motivator. Scholars are likely to agree that motivation is one of the key factors that influences the rate and success of the second or foreign language learning, and it provides the primary impetus to learning the foreign language and the driving force to sustain the long and often tedious learning process.

Therefore, the task of the teacher is to create a harmonious classroom atmosphere where learners can "participate actively in and contribute to classroom activities, explore alternative solutions to problems, evaluate critically the teachers' decision on management, and give alternative suggestions and initiate appropriate learning activities in and out class" [5].

Such organized activities are supposed to be appropriate, effective and relevant to the classroom teaching, best meet the students' needs and expectations and respond to the students' interests and abilities so that they will be highly motivated to perform in each stage of classroom activities.

Besides, teachers can introduce into the classroom "the kinds of motivating activities in which learner-centredness as a precursor to learner autonomy can be integrated" [6].

Through trial and error in the experience of English learning, learners can be helped to build and maintain self-confidence. It is a teacher's duty to encourage them in case of failure and convince them that their constant efforts are crucial to progress. A teacher will never miss a chance to praise a learner whenever he makes progress, however insignificant it may be. Teachers' praise and peers' admiration will be an inner drive great enough to stimulate him to make greater effort and then greater progress.

Learning-strategy Trainer. Learning strategies are defined as 'techniques, approaches or deliberate actions that students take in order to facilitate the learning, recall of both linguistic and context area information'. Oxford [7] also points out that 'learning strategies are behaviors or actions which learners use to make language learning more successful, self-directed and enjoyable'.

From the above definitions, we can find that learning strategy is believed to be the key to promoting learner autonomy, and an effective way to enhance learner autonomy. To foster students to be an independent learner, teachers will first raise students' awareness of the significance of strategy training. They will not follow teachers unless they realize the importance of learning strategy. Then before carrying out strategy training, teachers are strongly advised to gather the information on how much the students have already known about learning strategies, and to what extent they have used the strategies in language learning to make the strategy training well targeted and to meet the needs of a particular group of students.

On the basis of the investigation obtained from students, teachers need to make an analysis of data, introduce what they consider important and effective strategies to students, and suggest students choose and try what is considered most suitable ones.

When students have acquired learning strategies and have known how to deal with specific learning activities and fulfilled the required tasks for themselves, then they can be provided ample opportunities to try out the acquired strategies in different circumstances. If they fail to make satisfactory progress with their choices, teachers could first communicate with them to remove their misconception when it is obstructing their learning and their potential for autonomy, then assist them in modifying and reconstructing their cognitive knowledge. In this way, students can 
gradually learn how to develop their unique learning style and how to adapt themselves to the more efficacious strategies when the previous ones turn out to be fruitless.

Counselor. Learner autonomy is based on learner's independence and active attitude towards learning. The learner has the responsibility to make decisions and take charge of their learning. Learners are capable to control the learning process, autonomous learning is not a matter of institutional mode or compulsory task but a matter of learners' internal attitude. Learner autonomy is to recognize the self-directed and independent learning as well as the essential cooperation between teachers and learners [8].

Teacher role as counselor, Richards and Rodgers [9] argued: "The teacher-counselor is expected to exemplify an effective communicator seeking to maximize the meshing of speaker intention and hearer interpretation, through the use of paraphrase, confirmation and feedback."

Generally, teacher as counselor is to give advice and help to learners so that they can achieve more efficient learning. This kind of role can be realized by means of helping learners to become more self-monitoring, fulfill learner's aims and needs, as well as give feedback and support learners towards the target of autonomous learning.

Specifically, teacher as counselor is to introduce new directions and options to promote learner focus and reduce uncertainty; Teachers help learner to formulate specific goals and objectives to enable learner to focus on a manageable goal; Teachers offer advice and information, direction and ideas to help learner develop alternative strategies; Teachers provide encouragement and reinforcement to help learner persist, acknowledge and encourage effort; Teachers express a constructive reaction to learner's efforts to assist learner's awareness and capacity for selfappraisal.

Under teachers' counsel and supervision, the whole process of language teaching and learning will be operated at high efficiency, efforts of both teachers and students will be much rewarded.

Other Roles. Besides the above-mentioned roles, teachers are still required to perform other roles such as organizer, guide, coordinator, helper, communicator, facilitator, resource etc. One of the important roles among them is that of an organizer, because the success of many activities, no matter whether it is a specific role-play or a group discussion, depends on good organization and on the students' knowing exactly what they are expected to do. Then, in the early stage of autonomous training, learners may not have a clear idea about him, about the nature of self-directed learning, teachers' guidance will certainly save time and produce effect. In this case, teachers' job is to provide scaffolding to keep them from falling and later withdraw support as they gain greater autonomy. Further, teachers have to be able to establish a close collaboration with learners, especially in classroom where teachers and learners can have constructive interaction with each other, learn from each other, share findings, work out solutions to problems. Interaction directly influences learners' learning processes.

\section{Conclusion}

Learn autonomy is "an important and efficient approach to enhance language teaching " (R.P $\mathrm{Cao}[10])$ and "an economical solution to the problem of insufficient English teachers in China and as a remedy for lack of concern for individual needs "(X.L. Wang[11]). As important as it is, it is not normally an easy process to make learners become masters of autonomous learning, it depends on teachers and learners to cooperate and make shared effort. Implementation of learner autonomy has been encouraged by official educational policies in European countries, teachers in China have their duties to shift their roles for the lifelong benefit of Chinese learners.

\section{References}

[1] Holec, H.: Autonomy and Foreign Language Learning (Pergamon Press, Oxford 1981).

[2] Dichinson, L: Self-instruction in Language Learning (Cambridge University Press, Cambridge 1987). 
[3] Little. D.1990. Autonomy in language learning: some theoretical and practical considerations. London: Cilt.

[4] Kenny, B. 1993. For more autonomy. System 2I (4):43I-32.

[5] Chan Victoria: Learning Autonomously [J]. Journal of Future and Higher Education, 2001.

[6] Spratt, Mary, Humphreys, Gillian and Chan Victoria. 2002. Autonomy and Motivation.

[7] Oxford, R.L. 1990. Language learning Strategies: What every teacher should know. Moston, MA: Heinle\&Heinle.

[8] Usuki, 2002. Learner autonomy: learning through student's voice, Center for Language and Communication Studies., Trinity Coll, Dublin,

[9] Richards, J.C, Rodgers, T.S: Approaches and Methods in Languages Teaching (Cambridge University Press, Cambridge 1986).

[10]R.P. Cao, 2003.Respecting individual differences and promoting learner autonomy in China foreign teaching, Teaching English in China.

[11]X.L. Wang. 2003. Some theoretical and pedagogical consideration for Chinese EFL Context, Teaching English in China. 